\title{
Electrophysiologic Changes in Ventral Midbrain Dopaminergic Neurons Resulting from (+/-) -3,4-Methylenedioxymethamphetamine (MDMA-“Ecstasy")
}

\author{
Mauro Federici, Luca Sebastianelli, Silvia Natoli, Giorgio Bernardi, and Nicola B. Mercuri
}

Background: Although dopamine (DA) has been implicated in the psychostimulant properties of 3,4-methylenedioxymethamphetamine (MDMA), there is no detailed information on its modalities of action on single ventral midbrain dopaminergic neurons.

Methods: We examined the actions of MDMA on intracellularly recorded dopaminergic neurons maintained in slices.

Results: At $1 \mu \mathrm{mol} / \mathrm{L}, \mathrm{MDMA}$ depolarized and excited the cells; at $3 \mu \mathrm{mol} / \mathrm{L}$, either excited or inhibited the neurons. Interestingly, higher concentrations (10-30 $\mathrm{mmol} / \mathrm{L})$ inhibited firing through membrane hyperpolarization or caused an outward current. Whereas MDMA's excitatory effects were antagonized by pindolol, indicating involvement of 5-HT 1B receptors, the inhibitory effects were counteracted by sulpiride indicating involvement D2 receptors. Treatment of the cells with carbidopa eliminated MDMA-induced firing inhibition and membrane hyperpolarization. MDMA enhanced DA-induced cellular responses but reduced those of amphetamine. Cocaine-induced outward currents were not affected by MDMA. These actions are consistent with inhibition of the DA transporter. Moreover, MDMA depressed the GABA ${ }_{B}$ IPSP by activating $5-\mathrm{HT} 1 \mathrm{~B}$ receptors.

Conclusions: Our data demonstrate that 3-30 $\mu \mathrm{mol} / \mathrm{L}$ MDMA preferentially inhibits the dopaminergic cells via indirect activation of D2

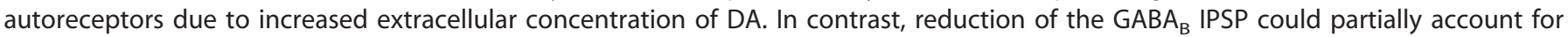
excitation caused by $1-3 \mu \mathrm{mol} / \mathrm{L}$ drug.

Key Words: Amphetamine, cocaine, dopamine (DA), DA transporter (DAT), electrophysiology, rat, serotonin (5-HT)

2 4-Methylenedioxymethamphetamine (MDMA; "ecstasy") is a recreational synthetic drug that induces sensations of well-being, decreased anxiety, emotional closeness to others, and emotional sensitivity in humans (Green et al. 2003; Vollenweider et al. 1998). Because of these characteristics, it is highly popular within "dance party" amateurs. It is generally believed that the actions of MDMA are mediated via an activation of the brain monoaminergic systems.

In particular, MDMA is an amphetamine analog that, by binding to the transporters for dopamine (DA) and serotonin (5-HT; Slikker et al. 1989), increases the extracellular levels of both, probably affecting either the plasmalemmal or vesicular uptake systems (Bankson and Cunningham 2001; Bogen et al. 2003; Gough et al. 1991; Johnson et al. 1986; McKenna et al. 1991; Rudnick and Wall 1992; White et al. 1996; Yamamoto and Spanos 1988). Therefore, the resultant interaction between DA and 5-HT on specific receptors accounts for most of its subjective effects (Bankson and Cunningham 2001; Gold et al. 1988; Liechti and Vollenweider 2001). With regard to the functions of MDMA on the dopaminergic neurons, it has been shown that MDMA inhibits the firing rate of ventral tegmental area cells (Gifford et

From the Laboratory of Experimental Neurology, Fondazione Santa LuciaIRCCS and Neurological Clinic, University of Rome Tor Vergata, Rome, Italy.

Address reprint requests to Nicola B. Mercuri, M.D., Laboratory of Experimental Neurology, Fondazione Santa Lucia-Centro Europeo di Ricerca sul Cervello (CERC) Via del Fosso di Fiorano, 64-00142 Roma, Italy; e-mail: mercurin@med.uniroma2.it.

Received October 4, 2006; revised November 16, 2006; accepted November $28,2006$. al. 1996; Kelland et al. 1989; Matthews et al. 1989; but see Piercey et al. 1990). Despite the fact that this inhibition is caused by DA receptor-dependent mechanisms (Gifford et al. 1996; White et al. 1996), no detailed information is available yet on the membrane processes involved. For instance, there are no data on the effective concentrations regulating neuronal activity. Furthermore, it remains unknown whether ecstasy is able to affect synaptic activity on the DAergic cells. It is also not known whether MDMAinduced electrophysiologic action on the DAergic cells is similar to those induced by amphetamine or cocaine. Therefore, the aim of this investigation was to examine the effects of MDMA on in vitro intracellularly recorded dopaminergic cells of the rat ventral mesencephalon.

\section{Methods and Materials}

\section{Brain Slice Preparation and Electrophysiology}

Wistar rats (28-35 days old) were anaesthetized with halothane and killed by decapitation. All experiments followed international guidelines on the ethical use of animals from the European Communities Council Directive of 24 November 1986 (86/609/EEC). The brain was rapidly removed from the skull and horizontal slices $(300-350 \mathrm{~mm})$ were cut in cold artificial cerebrospinal fluid (ACSF) using a vibratome and left to recover at $33^{\circ} \mathrm{C}$ for at least $20-30 \mathrm{~min}$ as described previously (Mercuri et al. 1995). A single midbrain slice was then transferred into a recording chamber and completely submerged in ACSF with a continuously flowing $(2.5 \mathrm{~mL} / \mathrm{min})$ solution at $35^{\circ} \mathrm{C}(\mathrm{pH} 7.4)$. This solution contained (in $\mu \mathrm{mol} / \mathrm{L}$ ) $126 \mathrm{NaCl} ; 2.5 \mathrm{KCl} ; 1.2 \mathrm{MgCl}_{2}$; $1.2 \mathrm{NaH}_{2} \mathrm{PO}_{4} ; 2.4 \mathrm{CaCl}_{2} ; 11$ glucose; $20 \mathrm{NaHCO}_{3}$ and was saturated with $95 \% \mathrm{O}_{2}$ and $5 \% \mathrm{CO}_{2}$.

\section{Intracellular Recordings}

The recording electrodes, prepared from 1.5-mm borosilicate capillaries (Clark Electromedical Instruments, Edenbridge, United 
Kingdom), were pulled with a P-97 Flaming/Brown puller (Sutter Instruments, Novato, California) and filled with a $2-\mu \mathrm{mol} / \mathrm{L} \mathrm{KCl}$ containing solution. The electrodes had a tip resistance of 35-80 $\mathrm{M} \Omega$. Membrane voltage and current signals were recorded using an Axoclamp-2B amplifier (Axon Instruments, Foster City, California). Under single-electrode voltage clamp $(-60 \mathrm{mV}$, holding potential, $\mathrm{V}_{\text {hold }}$ ), the switching frequency was $3-3.5 \mathrm{KHz}$, and a duty cycle of $30 \%$ was used. The headstage voltage was continuously monitored throughout the experiment on a separate oscilloscope to ensure sufficient decay of the electrode transient. The signals were digitized by use of an A/D converter (Digidata 1322 A, Axon Instruments) and saved in a computer with Clampex 9 software (Axon Instruments) for offline analysis.

\section{Synaptic Potentials}

$\mathrm{GABA}_{\mathrm{B}}$-mediated inhibitory potentials were evoked with a train of pulses ( $4-8$ stimuli of $70 \mathrm{sec}$ at $8-20 \mathrm{~V}$, delivered at $70 \mathrm{~Hz}$ every $35 \mathrm{sec}$ ) applied with a bipolar tungsten electrode positioned within the ventral midbrain. The membrane potential was adjusted to between -60 and $-65 \mathrm{mV}$ (below firing threshold) with the injection of hyperpolarizing current. A cocktail of antagonists was used to isolate the inhibitory events: bicuculline methiodide $\left(50 \mu \mathrm{mol} / \mathrm{L}, \mathrm{GABA}_{\mathrm{A}}\right)$, strychnine ( $1 \mu \mathrm{mol} / \mathrm{L}$, glycine $)$, prazosin $(300 \mathrm{nmol} / \mathrm{L}, \alpha 1)$, 6-cyano-7-nitroquinoxaline-2,3-dione (CNQX, $10 \mu \mathrm{mol} / \mathrm{L}$; alpha-amino-3-hydroxy-5-methyl-4-isoxazole propionic acid), 2-amino-5-phosphonopentanoic acid (AP-5, $50 \mu \mathrm{mol} / \mathrm{L} ; \mathrm{N}$-methyl-D-aspartate), SCH 23390 (3-10 $\mu \mathrm{mol} / \mathrm{L} ; \mathrm{D} 1)$, and sulpiride (1-3 $\mu \mathrm{mol} / \mathrm{L} ; \mathrm{D} 2)$. The amplitude of synaptic potentials was measured from traces representing the average of four responses.

\section{Application of Drugs}

Drugs were prepared in stock solutions and bath applied at known concentrations via a three-way tap system. A complete exchange of the solution in the recording chamber occurred in about $1 \mathrm{~min}$. The following substances were used: dopamine hydrochloride (DA; $100 \mathrm{nmol} / \mathrm{L}-300 \mu \mathrm{mol} / \mathrm{L}$ ), cocaine hydrochloride $(30 \mu \mathrm{mol} / \mathrm{L}),(+)$-amphetamine sulphate $(30 \mu \mathrm{mol} / \mathrm{L})$, (+/-)-3,4-methylenedioxymethamphetamine (MDMA) (1-30 $\mu \mathrm{mol} / \mathrm{L})$, sulpiride $(1-3 \mu \mathrm{mol} / \mathrm{L})$, reserpine $(1 \mu \mathrm{mol} / \mathrm{L})$, bicuculline methiodide $(50 \mu \mathrm{mol} / \mathrm{L})$, strychnine $(1 \mu \mathrm{mol} / \mathrm{L})$, prazosin (300 nmol/L) (all from Sigma, Milan, Italy); pindolol (300 nmol/ L), 6-CNQX (10 $\mu \mathrm{mol} / \mathrm{L})$, carbidopa (300 $\mu \mathrm{mol} / \mathrm{L}), 2-\mathrm{AP}-5$ (50 $\mu \mathrm{mol} / \mathrm{L}$ ), SCH $23390(3-10 \mu \mathrm{mol} / \mathrm{L}$ ) (all from Tocris Cookson, Bristol, United Kingdom).

\section{Systemic Injection of Reserpine}

A group of rats received intraperitoneal (IP) injections of reserpine, $5-8 \mathrm{mg} / \mathrm{kg}, 14-24$ hours before the electrophysiologic experiments. This pharmacological treatment caused a profound akinetic rigid state for at least 3 days (Mercuri et al. 1998). Control animals received vehicle IP injections.

\section{Data Analysis}

The data are expressed as mean \pm SEM. They were evaluated with Student's $t$ test for paired observations. The threshold level of significance for all analyses was $p<.05$.

To estimate the $\mathrm{EC}_{50}$ and maximal response, the concentration-response curve was fitted with a least squares regression using a logistic equation: $y=a x /(x+b)$, where $a$ is maximal effect; $x$ is drug concentration, and $b$ is the concentration attaining half-maximal effect.

\section{Results}

\section{Effects of MDMA on DAergic cells}

Intracellular recordings were made from 38 neurons of the substantia nigra pars compacta ( $\mathrm{SNc}$ ) and 19 of the ventral tegmental area (VTA). The presumed DAergic neurons were identified based on their location within the slice and electrophysiologic and pharmacologic properties, and thus by the presence of regular spontaneous firing activity, wide action potential $>1.1 \mathrm{msec}$ (as measured by the interval occurring between the initiation of spike's depolarization and the corresponding potential in the repolarizing phase), time-dependent $\mathrm{I}_{b}$ in response to hyperpolarizing voltage steps, and hyperpolarization caused by DA (3-30 $\mu \mathrm{mol} / \mathrm{L})$ (Grace and Onn 1989; Lacey et al. 1987; Mercuri et al. 1995). Only neurons meeting these criteria were studied. Because no substantial differences were observed between cells of the SNc and VTA, the data were pooled.

The superfusion of MDMA ( $1 \mu \mathrm{mol} / \mathrm{L})$ caused a slight increase of the spontaneous activity of the DAergic neurons $(1.5 \pm .4 \mathrm{~Hz}$ vs. $1.7 \pm .4 \mathrm{~Hz}, n=7, p<.01)$ that was associated with a membrane depolarization of $2-3 \mathrm{mV}$ (Figure $1 \mathrm{~A}$ ). When the dopaminergic cells $(n=9)$ were superfused with $(3 \mu \mathrm{mol} / \mathrm{L})$ MDMA, the spontaneous firing rate was almost blocked (1.4 \pm .7 Hz vs. $4 \pm .1 \mathrm{~Hz}, n=5, p<.01)$ or slightly increased $(1.3 \pm .5$ $\mathrm{Hz}$ vs. $1.7 \pm .3 \mathrm{~Hz}, n=4, p<.01)$. Interestingly, MDMA (10 $\mu \mathrm{mol} / \mathrm{L}$ ) silenced the spontaneous firing of all the tested neurons ( $n=8$ ) by hyperpolarizing the membrane potential $(5.7 \pm 1.4$ $\mathrm{mV}$; Figure $1 \mathrm{~B}$ ). These effects required $2-5 \mathrm{~min}$ to reach a steady state, and washout occurred after 4-8 min perfusion with standard solution. The inhibition of firing activity and membrane hyperpolarization caused by MDMA were counteracted by the superfusion of the DA D2 receptor antagonist sulpiride (1 $\mu \mathrm{mol} / \mathrm{L} ; n=5$; Figure $1 \mathrm{C}$ ). Interestingly, in the presence of sulpiride $(1 \mu \mathrm{mol} / \mathrm{L})$, MDMA $(10 \mu \mathrm{mol} / \mathrm{L})$ depolarized the DAergic cells by $3-4 \mathrm{mV}$ and increased the spontaneous firing activity $(1.4 \pm .6 \mathrm{~Hz}$ control, $1.8 \pm .5 \mathrm{~Hz}$ in the presence of MDMA 10 $\mu \mathrm{mol} / \mathrm{L}, n=6, p<.01)$.

\section{Catecholaminergic Depleting Treatment and Responses to MDMA}

Pretreatment of the rats with reserpine and the superfusion of the slices with $(1 \mu \mathrm{mol} / \mathrm{L})$ reserpine did not affect the MDMAinduced inhibition of the DAergic cells (Figure 2A; control hyperpolarization $4.5 \pm .7 \mathrm{mV}, n=6$, in the presence of reserpine $4.7 \pm .5 \mathrm{mV}, n=4, p>.05)$. Only subsequent treatment of the cells with carbidopa (300 $\mu \mathrm{mol} / \mathrm{L}$ for $15-25 \mathrm{~min})$, a dopa-decarboxylase enzyme inhibitor that changed neither the spontaneous firing activity nor the membrane potential level (Mercuri et al. 1990), abolished the inhibition of firing and membrane hyperpolarization caused by MDMA ( $n=4$; Figure $2 \mathrm{~B})$. Under these conditions, MDMA $(30 \mu \mathrm{mol} / \mathrm{L})$ in a carbidopa-treated slice caused a small depolarization and an increase in firing $(1.4 \pm .5 \mathrm{~Hz}$ control, $1.8 \pm .4 \mathrm{~Hz}, n=4, p<$ .01) that was not antagonized by prazosin $(300 \mathrm{nmol} / \mathrm{L})$ but was counteracted by the 5-HT-1B antagonist pindolol (300 $\mathrm{nmol} / \mathrm{L} ; n=4$; Figure 2C).

\section{MDMA Potentiates DA-Induced Responses}

The membrane-outward currents caused by the superfusion of DA $(300 \mathrm{nmol} / \mathrm{L}-30 \mu \mathrm{mol} / \mathrm{L})$ on voltage-clamped DA neurons at $-60 \mathrm{mV}$ (below threshold for spontaneous action potential initiation) were potentiated by MDMA (10 $\mu \mathrm{mol} / \mathrm{L}$; Figure 3A, a). Thus, the $\mathrm{EC}_{50}$ for DA in control condition was $16.7 \pm 8 \mu \mathrm{mol} / \mathrm{L}$ 
A

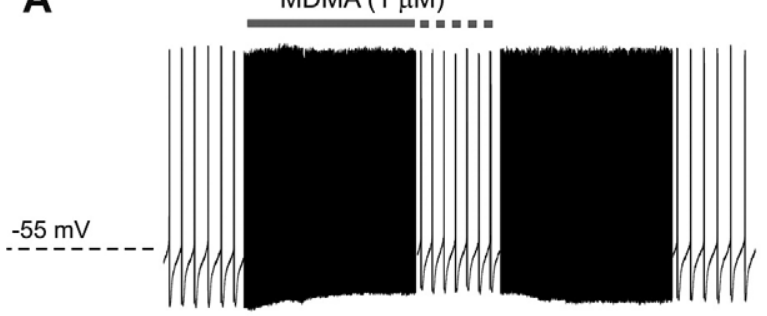

B
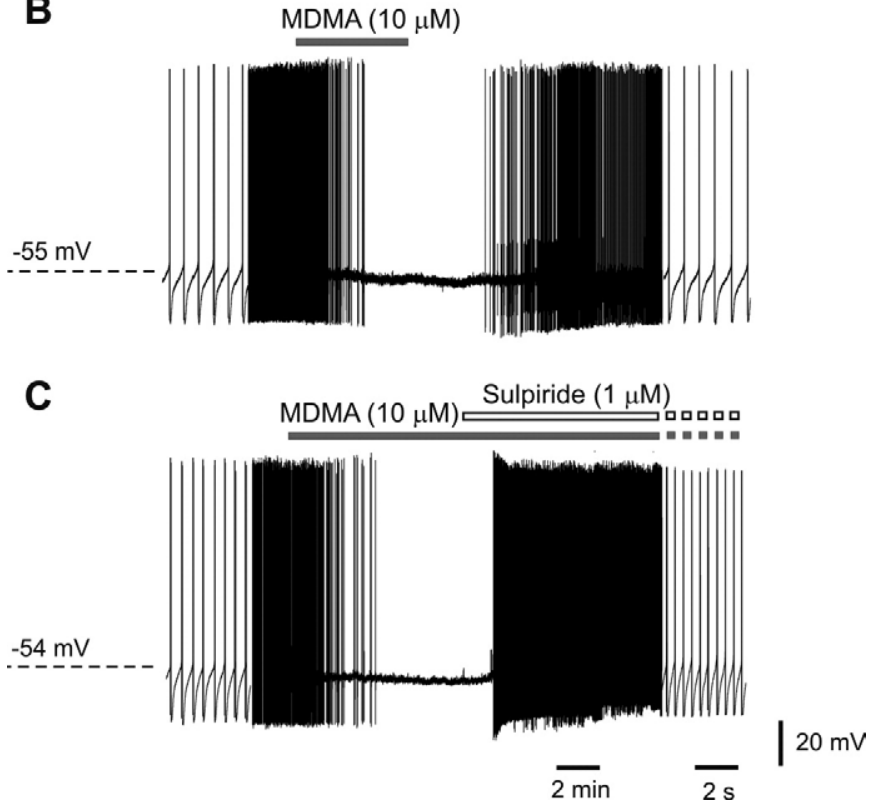

Figure 1.3,4-Methylenedioxymethamphetamine (MDMA) and dopaminergic cells. (A) A low concentration of MDMA $(1 \mu \mathrm{mol} / \mathrm{L}$, applied in the bath for the period indicated by the bar) caused reversible cellular excitation. (B) MDMA $(10 \mu \mathrm{mol} / \mathrm{L})$ blocked the spontaneous firing by hyperpolarizing the membrane. (C) The inhibitory effects of MDMA were antagonized by the concomitant superfusion of sulpiride $(1 \mu \mathrm{mol} / \mathrm{L})$. Note that in the presence of the D2 antagonist the firing rate was activated by MDMA. All the traces were obtained from the same neuron of the substantia nigra pars compacta. To show individual action potentials, in this and the following figures, the time speed has been transiently increased. Further, in this and the following figures, during the changes in speed, the continuous bar line that indicates the period of MDMA application continues in a dashed line. The lower dashed line indicates $-55 \mathrm{mV}$.

$(n=4)$, and the $\mathrm{EC}_{50}$ for DA in the presence of MDMA $(10 \mu \mathrm{mol} / \mathrm{L})$ was $8.2 \pm 4(n=5)$. Interestingly, $\mathrm{DA} \mathrm{EC}_{50}$ was reduced by a factor of 2.03 (Figure 3A, b). Moreover, the amplitude of the outward current caused by DA $(3 \mu \mathrm{mol} / \mathrm{L})$ was enhanced by MDMA in a concentration-dependent manner, with an $\mathrm{EC}_{50}$ of $1.2 \pm .8 \mu \mathrm{mol} / \mathrm{L}, n=8$ (Figure $3 \mathrm{~B}, \mathrm{a}, \mathrm{b}$ )

\section{MDMA Reduces Amphetamine-Induced, but Not Cocaine-Induced, Outward Currents}

Under control conditions, the superfusion of amphetamine ( $30 \mu \mathrm{mol} / \mathrm{L})$ on the DAergic neurons caused an outward current (122.2 $\pm 24.4 \mathrm{pA}, n=5$, Figure 4A, a) (Mercuri et al. 1989; Scarponi et al. 1999). The subsequent application of MDMA (10 $\mu \mathrm{mol} / \mathrm{L})$ on the same cells caused an outward current of $11.7 \pm$ $3.8 \mathrm{pA}(n=7)$ but determined an attenuation of the amphetamine-induced outward response (Figure 4A, b and B, a). Thus, the amplitude of the peak response induced by amphetamine in the presence of MDMA was $53.8 \pm 11.3 \%(n=7, p<.01)$ of control. These effects are similar to those of cocaine (Scarponi et al. 1999).

To assess whether MDMA is also able to reduce the outward response caused by cocaine, as it does with amphetamine, we first applied cocaine $(30 \mu \mathrm{mol} / \mathrm{L})$ to induce an outward current of $35 \pm 7 \mathrm{pA}(n=4 ;$ Figure $4 \mathrm{~B}, \mathrm{a})$ and then reapplied cocaine $(30$ $\mu \mathrm{mol} / \mathrm{L})$ in the presence MDMA $(10 \mu \mathrm{mol} / \mathrm{L})$. Under this conditions, the outward current induced by cocaine was $33 \pm 6 \mathrm{pA}$ ( $n=4 ; p>.05$; Figure $4 \mathrm{~B}, 4 \mathrm{~b}$ ), but the peak of the total outward response was augmented because of the MDMA-induced current $(8.5 \pm 2.8 \mathrm{pA} ; n=4$; Figure $4 \mathrm{~B}, 4 \mathrm{~b})$.

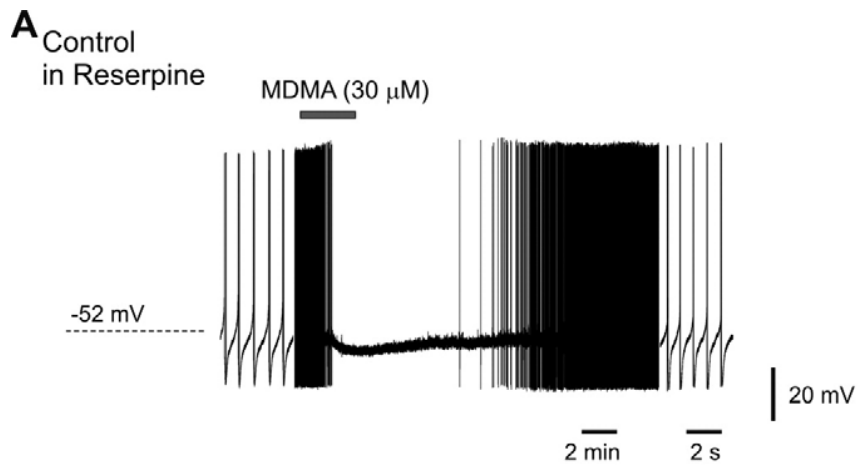

B

Plus Carbidopa

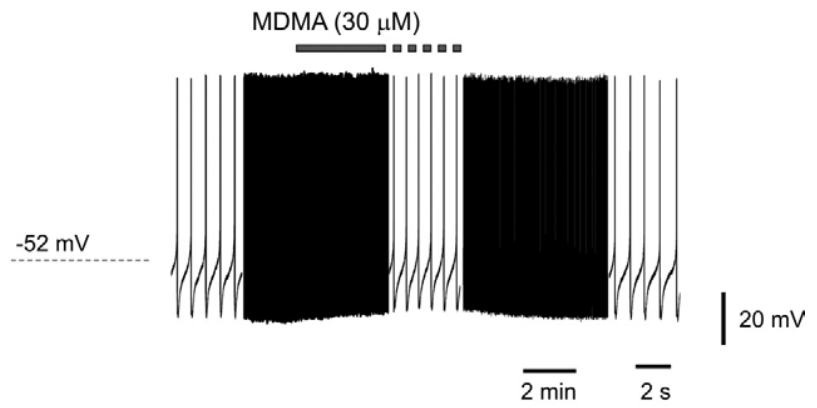

C

Plus Carbidopa and Pindolol

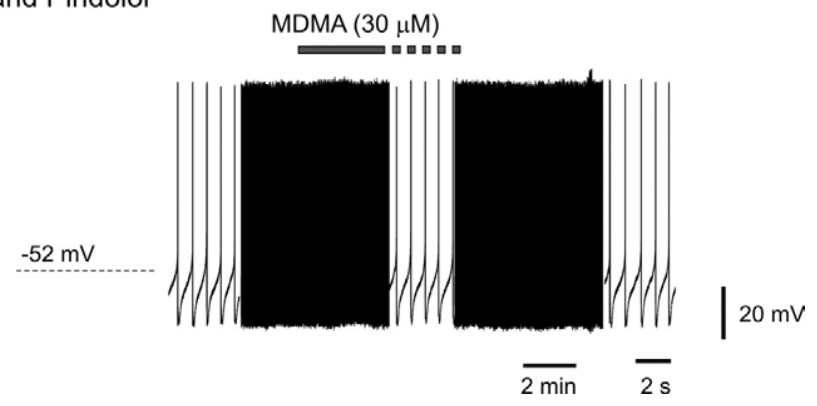

Figure 2. 3,4-Methylenedioxymethamphetamine (MDMA) responses and dopamine (DA) depletion in the dopaminergic cells. (A) Control in reserpine: the voltage trace illustrates a reversible inhibitory and hyperpolarizing action of MDMA (30 $\mu \mathrm{mol} / \mathrm{L})$. This cell has been recorded from a reserpinetreated animal and in the presence of bath-applied reserpine $(1 \mu \mathrm{mol} / \mathrm{L})$. (B) Plus carbidopa: a subsequent treatment with carbidopa ( $300 \mu \mathrm{mol} / \mathrm{L}$ for $15-25$ min) eliminated the inhibitory effects of MDMA that instead depolarized and excited this cell. (C) Plus carbidopa and pindolol: the superfusion of pindolol $(300 \mathrm{nmol} / \mathrm{L})$ antagonized the excitatory action of MDMA. Prazosin $(300 \mathrm{nmol} / \mathrm{L})$ was present throughout the experiment. Note that all the traces were obtained from the same VTA dopaminergic neuron. 
A

a Control

In MDMA $(10 \mu \mathrm{M})$

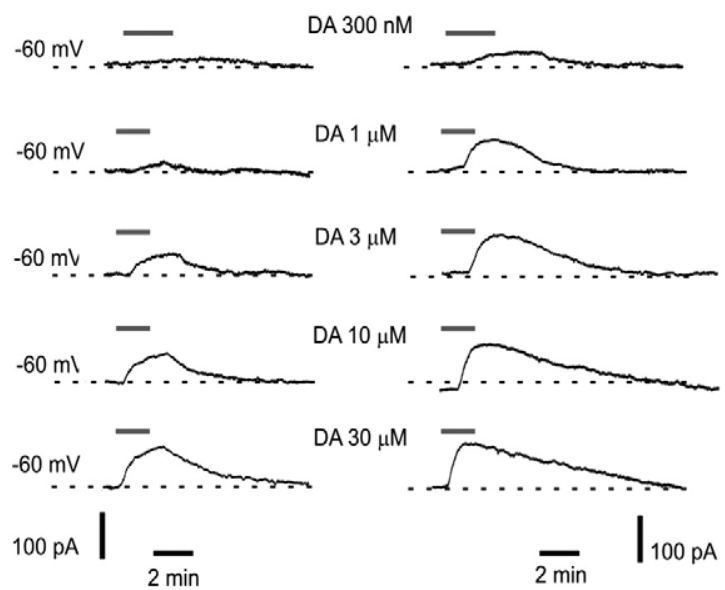

B

a

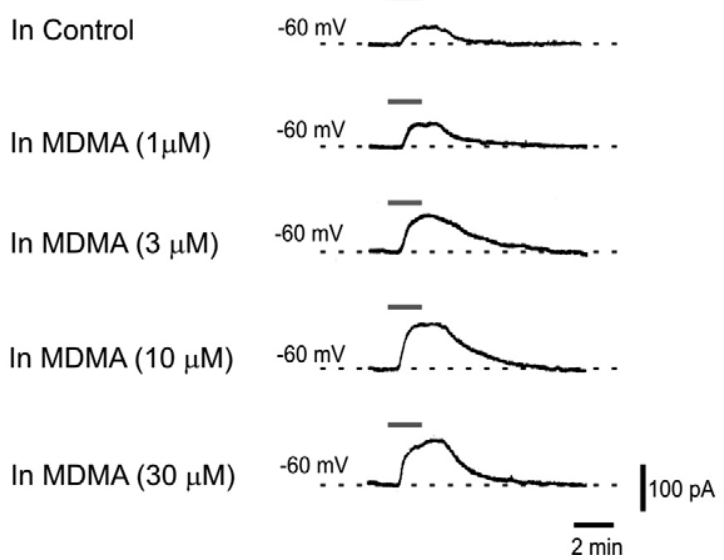

b

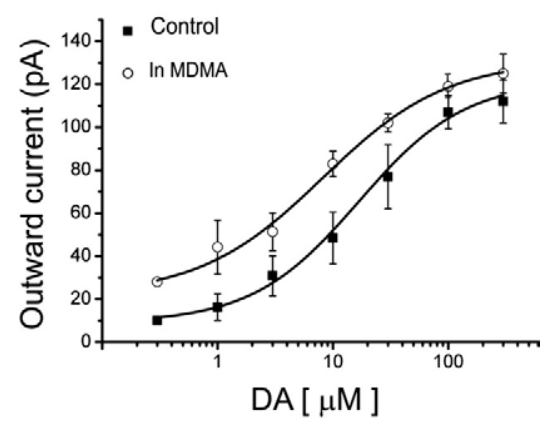

b

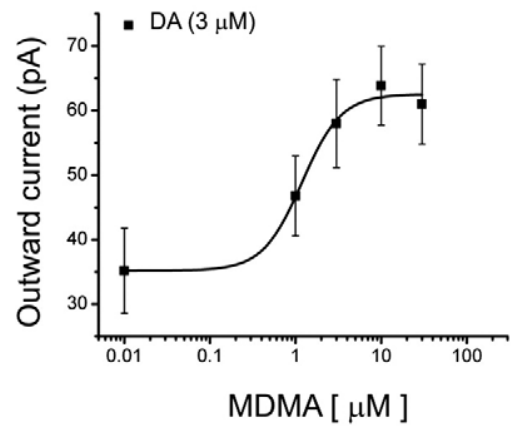

Figure 3. 3,4-Methylenedioxymethamphetamine (MDMA) potentiates dopamine (DA) responses in the dopaminergic cells. (A, a) The outward currents caused by increasing concentrations of DA (control) were augmented in amplitude and duration in the presence of MDMA (10 $\mu \mathrm{mol} / \mathrm{L}$; the period of application is indicated by bars). (A, b) concentration-response curves of DA in control conditions and in the presence of MDMA (10 $\mu \mathrm{mol} / \mathrm{L}$ ) (each point is a mean obtained from 4-5 observations; vertical lines indicate SE). Note the leftward shift caused by ecstasy. (B, a) The outward current caused by DA ( $3 \mu \mathrm{mol} / \mathrm{L}$ ) were potentiated by MDMA. $(B, b)$ The curve indicates the concentration-dependent effects of MDMA.

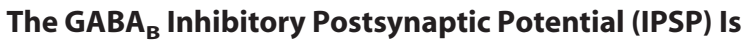 Reduced by MDMA}

To assess whether MDMA could eventually increase the extracellular content of 5-HT in the ventral midbrain, we studied its action on the $\mathrm{GABA}_{\mathrm{B}}$ postsynaptic potential. A typical effect caused by an increased serotoninergic tone in the ventral midbrain is a depression of the $\mathrm{GABA}_{\mathrm{B}}$ postsynaptic potential on the DAergic neurons (Cameron and Williams 1994; Johnson et al. 1992). Accordingly, MDMA (10 $\mu \mathrm{mol} / \mathrm{L})$ reversibly diminished the amplitude of the $\mathrm{GABA}_{\mathrm{B}}$ inhibitory potential by $49.5 \% \pm 7 \%$ ( $n=4, p<.05)$, and this effect was antagonized by pindolol (300 $\mathrm{nmol} / \mathrm{L} ; n=4, p<.05$; Figure 5).

\section{Discussion}

Our findings demonstrate that the illicit drug MDMA affects the activity of the dopaminergic cells in the mammalian brain. The drug has a dual effect on firing: at low concentrations it excites these neurons, whereas at higher concentrations it inhibits them. The predominant response seen with MDMA (3-30 $\mu \mathrm{mol} / \mathrm{L}$ ) is a decreased firing activity caused by a membrane hyperpolarization that depends on activation of D2 autoreceptors. This is clearly supported by the blocking effects obtained with the specific D2 receptor antagonist sulpiride. In agreement with these data, 1) inhibitory effects of MDMA, mediated by DA receptors, have been already described on VTA DAergic cells recorded in vivo (Gifford et al. 1996; White et al. 1996); 2) the systemic injection of MDMA elevates extracellular DA in the substantia nigra (Yamamoto et al. 1995).

The observation that the dopa-decarboxylase inhibitor carbidopa blocked MDMA-induced inhibition demonstrates that it is mediated indirectly. In fact, this inhibition is likely caused by an increased concentration of new synthesized DA in the extracellular space. The unmodified inhibitory responses of MDMA on the DAergic cells in reserpine-treated animals indicate that this 
A

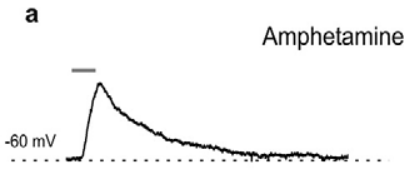

B

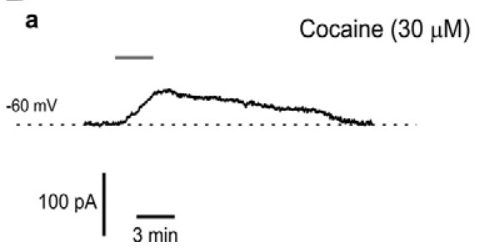

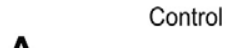

b

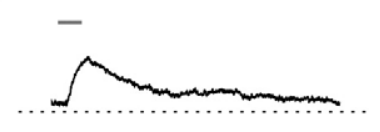

b

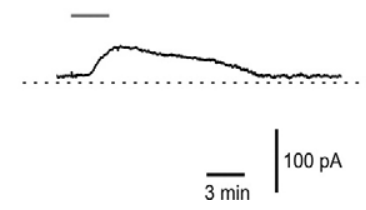

In MDMA $(10 \mu \mathrm{M})$

Figure 4. Effects of 3,4-Methylenedioxymethamphetamine (MDMA) on amphetamine- and cocaine-induced responses. ( $A, a, b)$ outward current caused by amphetamine $(30 \mu \mathrm{mol} / \mathrm{L})$ were depressed by MDMA $(10 \mu \mathrm{M})$. $(c, d)$ The cocaine-induced outward current was not diminished by the same concentration of MDMA. Dopaminergic neurons were voltage clamped at $-60 \mathrm{mV}$. Note the outward current caused by MDMA. The neurons shown in $A$ and $B$ are different.

recreational drug does not release DA from stores characterized by the presence of the vesicular monoamine transporter (VMAT). Consequently, despite the fact that ecstasy is an amphetamine congener, it does not redistribute, as amphetamine does, DA from vesicles to the cytosol, promoting a reverse transport of the catecholamine from storage sites (Sulzer et al. 2005). Therefore, store-independent diffusion mechanisms of DA, at least in the dendrites of the mesencephalic cells, might account for the electrophysiologic actions of the drug. This is consistent with recent pharmacologic studies that have found that MDMA releases DA from storage vesicles with a relatively high EC50 (Partilla et al. 2006). Because the electrophysiologic effects of MDMA in the hippocampus appear to be mediated by an increased release of 5 -HT from stores sensitive to reserpine (Mlinar and Corradetti 2003), there may be differences in the modalities of MDMA-induced release between DA and 5-HT or between dendritic and synaptic compartments.

More interesting is the evidence that MDMA 1) potentiates the cellular responses to exogenously applied DA by impeding catecholamine reentering the cells (Pifl et al. 1995) and 2) reduces the electrophysiologic actions of amphetamine by inhibiting a DAT-mediated DA efflux (Scarponi et al. 1999), suggesting that it behaves, at least electrophysiologically, as a classical DA uptake blocker (Lacey et al. 1990). In addition, the observation that an amphetamine-inhibiting concentration of MDMA does not significantly attenuate but augments the peak cellular response to cocaine supports the concept that both drugs have similar converging effects blocking DAT. Consequently, during the action of MDMA, DA, normally released from the soma and dendrites of the dopaminergic cells in the extracellular space (Cheramy et al. 1981), is not properly cleared by the blocked DAT. Actions similar to those caused by MDMA on the dopaminergic neurons, which are also reserpine-resistant and carbidopa-sensitive, have been described at the neuronal level and said to be caused by the DA uptake blockers cocaine, amineptine, and methylphenidate (Federici et al. 2005; Lacey et al. 1990; Mercuri et al. 1991). Thus, cocaine-like actions of MDMA could be consistent with the firing inhibition of the mesencephalic DAergic neurons (Einhorn et al. 1988; Lacey et al. 1990). Furthermore, the concentration of MDMA potentiating DA re- sponses is in a micromolar range comparable to the inhibition of DA reuptake into striatal synaptosomes (Crespi et al. 1997) and the control of MPP + release in recombinant cellular systems (Pifl et al. 2005).

Remarkably, the EC50 for the concentration effects of DA was decreased by a factor of 2 in the presence of MDMA. A similar leftward shift of the DA concentration effect curve has been observed with other uptake blockers, suggesting that this value is a typical feature encountered when DAT is pharmacologically inhibited (Federici et al. 2005; Lacey et al. 1990; Mercuri et al. 1991).

There is also clear experimental evidence suggesting that MDMA increases not only the extracellular level of DA but also of 5-HT in the brain (Gough et al. 1991; Mayerhofer et al. 2001). Accordingly, we observed an increase of the spontaneous firing of the DAergic cells at a low concentration of MDMA and, using higher concentrations, when the D2 receptors were blocked. In addition, the drug caused a reversible depression of the GABAB IPSP (Cameron and Williams 1994; Johnson et al. 1992). The antagonism of these MDMA-induced effects obtained with pindolol suggests that the MDMA-induced firing excitation is likely caused by disinhibition via an augmented concentration of serotonin within the ventral mesencephalon. Consequently, serotonin stimulates 5 -HT $1 \mathrm{~B}$ receptors localized on GABA afferents originating from the striatum and the nucleus accumbens. It has been proposed that these 5-HT 1B-mediated effects could play a role in the hyperactivity caused by MDMA (Scearce-Levie et al. 1999).

Taken together, our functional experiments suggest that the recreational drug MDMA has effects on dopaminergic neurons principally attributable to an inhibition of the plasma membrane transporters for DA and to an increased extracellular concentration of 5-HT. Thus, when relatively low concentration of the drug are present in the brain, two distinct processes accounts for the increase in the extracellular levels of DA: 1) an initial spikedependent process mediated by the disinhibitory effects of 5-HT and 2) a DAT-mediated process that impedes DA reentering in to the cell. When higher concentrations of MDMA are present in the brain, however, there is a firing inhibition in the dopaminergic cells, but the drug produces a rise in extracellular DA that is mainly dependent on DAT-mediated processes.

Despite our electrophysiologic results supporting an inhibition of DAT, it may be possible that the overall increase of the extracellular level of DA caused by MDMA could depend on the activation of reserpine-resistant diffusion exchange mechanisms (Benloucif and Galloway 1991; Camarero et al. 2002; Nash and Brodkin 1991), reverse transport (reviewed by Green et al. 2003), and channel-like modes of efflux (Hilber et al. 2005).

\section{Conclusions}

In this investigation, we have characterized the effects of MDMA on the DAergic neurons that could regulate the extracellular level of dopamine in the brain. In particular, the potentiation of the DA-induced neuronal responses, caused by the blocking effects of MDMA on DAT, could facilitate the activation of DA receptors principally localized at the amine release sites (Cragg and Rice 2004). Interestingly, the same facilitation of DA responses is not observed with drugs that have transportermediated releasing actions (Mercuri et al. 1989) and instead release DA at either the synaptic or the extrasynaptic sites. This is an important point because most of the subjective psychomotor effects of ecstasy are modulated by an increase of DA and 


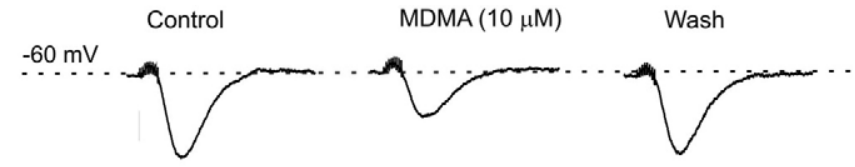

In Pindolol (300 nM)
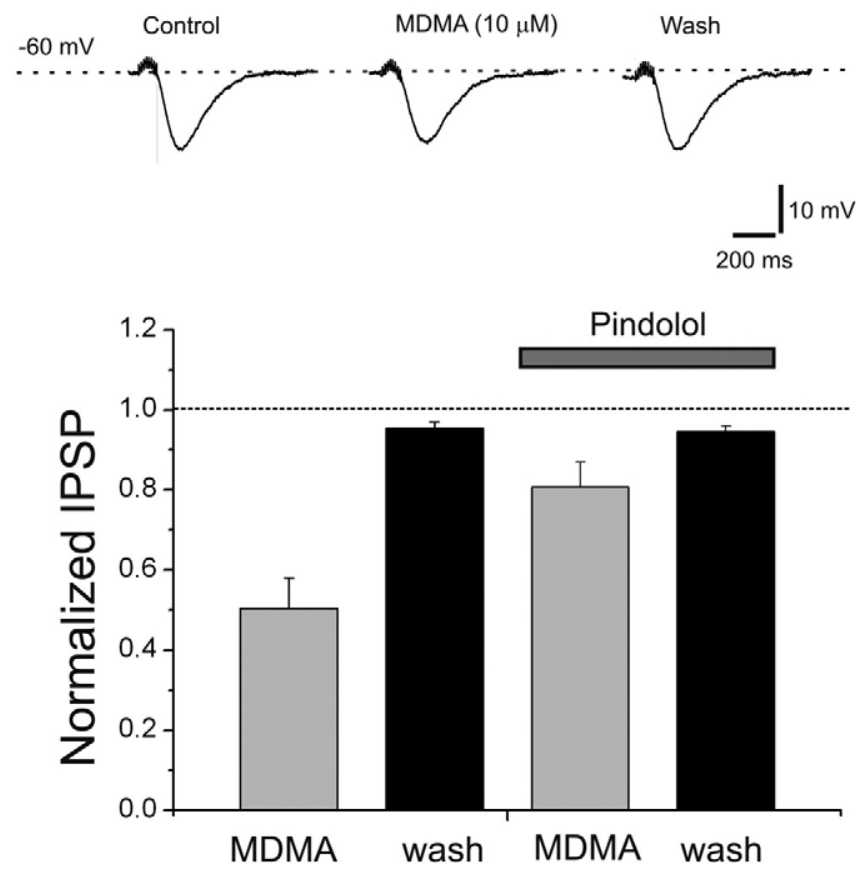

Figure 5. 3,4-Methylenedioxymethamphetamine (MDMA) depresses the $G_{B A B}$ slow-inhibitory synaptic potential in the dopaminergic cells. (Top) The voltage trace illustrates the reversible depression of the GABA $A_{B}$ inhibitory postsynaptic potential (IPSP) induced by MDMA (10 $\mu \mathrm{mol} / \mathrm{L})$. This depressant action was antagonized by the $5-\mathrm{HT} 1_{\mathrm{B}} /$ beta antagonist pindolol ( 300 $\mathrm{nmol} / \mathrm{L}$ ); to avoid spikes generation, the membrane potential was held at -60 $\mathrm{mV}$ in this dopaminergic cell by injecting a hyperpolarizing current (110 pA) through the intracellular electrode. (Bottom) The bars indicate the normalized antagonism of the MDMA-induced GABA $B$ IPSP depression obtained with pindolol $(300 \mathrm{nmol} / \mathrm{L})$ in all the experiments $(\mathrm{n}=4)$.

5-HT in the synaptic cleft (Fletcher et al. 2002; Kelly and Iversen 1976; Liechti and Vollenweider 2001). To understand the psychostimulant effects of MDMA, our results, obtained at the level of midbrain DA perikaria, need to be integrated with the actions of the drug at the axon terminals, which are largely responsible for the net DA efflux in the central nervous system. Furthermore, additional serotoninergic effects of MDMA's hepatic metabolites in vivo (Jones et al. 2005) that could participate in the overall action of the drug should be considered.

\section{Clinical Implications}

The blocking effect of DAT caused by MDMA contributes to its addictive properties, its self-administration and human misuse, and its robust locomotor activation (Bankson and Cunningham 2001; Baumann et al. 2005; Ratzenboeck et al. 2001; Schenk et al. 2003). It may also account for the drug's antiparkinsonian and antidyskinetic effects in animal models of extrapyramidal disorders (Iravani et al. 2003; Schmidt et al. 2002).

This work was supported by a grant from the Ministero della Salute and by two FIRB grants (Grants RBNEO1WY7P_O1O and RBNE017555_006) to N.B.M.
Bankson MG, Cunningham KA (2001): 3,4-Methylenedioxymethamphetamine (MDMA) as a unique model of serotonin receptor function and serotonin-dopamine interactions. J Pharmacol Exp Ther 297:846-852.

Baumann MH, Clark RD, Budzynski AG, Partilla JS, Blough BE, Rothman RB (2005): N-substituted piperazines abused by humans mimic the molecular mechanism of 3,4-methylenedioxymethamphetamine (MDMA, or "Ecstasy"). Neuropsychopharmacol 30:550-560.

Benloucif S, Galloway MP (1991): Facilitation of dopamine release in vivo by serotonin agonists: Studies with microdialysis. Eur J Pharmacol 200:1-8.

Bogen IL, Haug KH, Myhre O, Fonnum F (2003): Short- and long-term effects of MDMA ("ecstasy") on synaptosomal and vesicular uptake of neurotransmitters in vitro and ex vivo. Neurochem Int 43:393-400.

Camarero J, Sanchez V, O'Shea E, Green AR, Colado MI (2002): Studies, using in vivo microdialysis, on the effect of the dopamine uptake inhibitor GBR 12909 on 3,4-methylenedioxymethamphetamine ("ecstasy")-induced dopamine release and free radical formation in the mouse striatum. J Neurochem 81:961-972.

Cameron DL, Williams JT (1994): Cocaine inhibits GABA release in the VTA through endogenous 5-HT. J Neurosci 14:6763-6767.

Cheramy A, Leviel V, Glowinski J (1981): Dendritic release of dopamine in the substantia nigra. Nature 289:537-542.

Cragg SJ, Rice ME (2004): DAncing past the DAT at a DA synapse. Trends Neurosci 27: 270-277.

Crespi D, Mennini T, Gobbi M (1997): Carrier-dependent and Ca(2+)-dependent 5-HT and dopamine release induced by (+)-amphetamine, 3,4methylendioxymethamphetamine, $\mathrm{p}$-chloroamphetamine and (+)-fenfluramine. Brit J Pharmacol 121:1735-1743.

Einhorn LC, Johansen PA, White FJ (1988): Electrophysiological effects of cocaine in the mesoaccumbens dopamine system: Studies in the ventral tegmental area. J Neurosci 8:100-112.

Federici M, Geracitano R, Bernardi G, Mercuri NB (2005): Actions of methylphenidate on dopaminergic neurons of the ventral midbrain. Biol Psychiatry 57:361-365.

Fletcher PJ, Korth KM, Robinson SR, Baker GB (2002): Multiple 5-HT receptors are involved in the effects of acute MDMA treatment: Studies on locomotor activity and responding for conditioned reinforcement. Psychopharmacol 162:282-291.

Gifford AN, Minabe Y, Toor A, Wang RY, Ashby CR Jr (1996): Examination of the action of 3,4-methylenedioxymethamphetamine on rat $A 10$ dopamine neurons. Synapse 23:52-57.

Gold LH, Koob GF, Geyer MA (1988): Stimulant and hallucinogenic behavioral profiles of 3,4-methylenedioxymethamphetamine and $\mathrm{N}$-ethyl-3,4methylenedioxyamphetamine in rats. J Pharmacol Exp Ther 247:547555.

Gough B, Ali SF, Slikker W Jr, Holson RR (1991): Acute effects of 3,4-methylenedioxymethamphetamine (MDMA) on monoamines in rat caudate. Pharmacol Biochem Behav 39:619-623.

Grace AA, Onn SP (1989): Morphology and electrophysiological properties of immunocytochemically identified rat dopamine neurons recorded in vitro. J Neurosci 9:3463-3481.

Green AR, Mechan AO, Elliott JM, O'Shea E, Colado MI (2003): The pharmacology and clinical pharmacology of 3,4-methylenedioxy methamphetamine (MDMA, "Ecstasy"). Pharmacol Rev 55:463-508.

Hilber B, Scholze P, Dorostkar MM, Sandtner W, Holy M, Boehm S, et al. (2005): Serotonin-transporter mediated efflux: A pharmacological analysis of amphetamines and non-amphetamines. Neuropharmacol 49: 811-819.

Iravani MM, Jackson MJ, Kuoppamaki M, Smith LA, Jenner P (2003): 3,4methylenedioxymethamphetamine (ecstasy) inhibits dyskinesia expression and normalizes motor activity in 1-methyl-4-phenyl-1,2,3,6tetrahydropyridine-treated primates. J Neurosci 23:9107-9115.

Kelland MD, Freeman AS, Chiodo LA (1989): (+/-)3,4-methylenedioxymethamphetamine-induces changes in the basal activity and pharmacological responsiveness of nigrostriatal dopamine neurons. Eur J Pharmacol 169:11-21.

Kelly PH, Iversen SD (1976): Selective 6-OHDA-induced destruction of mesolimbic dopamine neurons: Abolition of psychostimulant-induced locomotor activity in rats. Eur $J$ Pharmacol 40: 45-56.

Johnson MP, Hoffman AJ, Nichols DE (1986): Effects of enantiomers of MDA, MDMA and related analogues on $\left[{ }^{3} \mathrm{H}\right]$ serotonin and $\left[{ }^{3} \mathrm{H}\right]$ dopamine release from superfused brain slices. Eur J Pharmacol 132:269-276. 
Johnson SW, Mercuri NB, North RA (1992): 5-hydroxytryptamine1B receptors block the GABAB synaptic potential in rat dopamine neurons. J Neurosci 12:2000-2006.

Jones DC, Duvauchelle C, Ikegami A, Olsen CM, Lau SS, de la Torre R, Monks TJ (2005): Serotonergic neurotoxic metabolites of ecstasy identified in rat brain. J Pharmacol Exp Ther 313:422-431.

Lacey MG, Mercuri NB, North RA (1987): Dopamine acts on D2 receptors to increase potassium conductance in neurones of the rat substantia nigra zona compacta. J Physiol (Lond) 392:397-416.

Lacey MG, Mercuri NB, North RA (1990): Actions of cocaine on rat dopamine neurons in vitro. Brit J Pharmacol 99:731-735.

Liechti ME, Vollenweider FX (2001): Which neuroreceptors mediate the subjective effects of MDMA in humans? A summary of mechanistic studies. Hum Psychopharmacol 16:589-598.

Matthews RT, Champney TH, Frye GD (1989): Effects of (+-)3,4-methylenedioxymethamphetamine (MDMA) on brain dopaminergic activity in rats. Biochem Behav 33:741-747.

Mayerhofer A, Kovar KA, Schmidt WJ (2001): Changes in serotonin, dopamine and noradrenaline levels in striatum and nucleus accumbens after repeated administration of the abused drug MDMA in rats. Neurosci Lett 308:99-102.

McKenna DJ, Guan XM, Shulgin AT (1991): 3,4-Methylenedioxyamphetamine (MDA) analogues exhibit differential effects on synaptosomal release of ${ }^{3} \mathrm{H}$-dopamine and ${ }^{3} \mathrm{H}-5$-hydroxytryptamine. Pharmacol Biochem Behav 38:505-512.

Mercuri NB, Bonci A, Calabresi P, Stratta F, Bernardi G (1995): Properties of the hyperpolarization-activated cation current $\mathrm{I}_{\mathrm{h}}$ in rat midbrain dopaminergic neurons. Eur J Neurosci 7:462-469.

Mercuri NB, Calabresi P, Bernardi G (1989): The mechanism of amphetamineinduced inhibition of rat substantia nigra compacta neurones investigated with intracellular recording in vitro. Brit J Pharmacol 98:127-134.

Mercuri NB, Calabresi P, Bernardi G (1990): Responses of rat substantia nigra compacta neurones to L-DOPA. Br J Pharmacol 100:257-260.

Mercuri NB, Stratta F, Calabresi P, Bernardi G (1991): Electrophysiological effects of amineptine on neurones of the rat substantia nigra pars compacta: Evidence for an inhibition of the dopamine uptake system. Brit $J$ Pharmacol 104:700-704.

Mlinar B, Corradetti R (2003): Endogenous 5-HT, released by MDMA through serotonin transporter- and secretory vesicle-dependent mechanisms, reduces hippocampal excitatory synaptic transmission by preferential activation of 5-HT1B receptors located on CA1 pyramidal neurons. Eur J Neurosci 18:1559-1571.

Nash JF, Brodkin J (1991): Microdialysis studies on 3,4-methylenedioxymethamphetamine-induced dopamine release: Effect of dopamine uptake inhibitors. J Pharmacol Exp Ther 259:820-825.

Partilla JS, Dempsey AG, Nagpal AS, Blough BE, Baumann MH, Rothman RB (2006): Interaction of amphetamines and related compounds at the vesicular monoamine transporter. J Pharmacol Exp Ther 319:237-246.
Piercey MF, Lum JT, Palmer JR (1990): Effects of MDMA ("ecstasy") on firing rates of serotonergic, dopaminergic, and noradrenergic neurons in the rat. Brain Res 526:203-206.

Pifl C, Drobny H, Reither H, Hornykiewicz O, Singer EA (1995): Mechanism of the dopamine-releasing actions of amphetamine and cocaine: Plasmalemmal dopamine transporter versus vesicular monoamine transporter. Mol Pharmacol 47:368-373.

Pifl C, Nagy G, Berenyi S, Kattinger A, Reither H, Antus S (2005): Pharmacological characterization of ecstasy synthesis byproducts with recombinant human monoamine transporters. J Pharmacol Exp Ther 314:346354.

Ratzenboeck E, Saria A, Kriechbaum N, Zernig G (2001) Reinforcing effects of MDMA ("ecstasy") in drug-naïve and cocaine-trained rats. Pharmacology 62:138-144.

Rudnick G, Wall SC (1992): The molecular mechanism of "ecstasy" [3,4methylenedioxymethamphetamine (MDMA)]: Serotonin transporters are targets for MDMA-induced serotonin release. Proc Natl Acad Sci U S A 89:1817-1821.

Scarponi M, Bernardi G, Mercuri NB (1999): Electrophysiological evidence for a reciprocal interaction between amphetamine and cocaine-related drugs on rat midbrain dopaminergic neurons. Eur $J$ Neurosci 11:593-598.

Scearce-Levie K, Viswanathan SS, Hen R (1999): Locomotor response to MDMA is attenuated in knockout mice lacking the $5-\mathrm{HT} 1 \mathrm{~B}$ receptor. Psychopharmacol (Berlin) 141:154-161.

Schenk S, Gittings D, Johnstone M, Daniela E (2003): Development, maintenance, and temporal pattern of self-administration maintained by ecstasy (MDMA) in rats. Psychopharmacol 169:21-27.

Schmidt WJ, Mayerhofer A, Meye A, Kovar KA (2002): Ecstasy counteracts catalepsy in rats, an anti-parkinsonian effect? Neurosci Lett 330:251-254.

Slikker W Jr, Holson RR, Ali SF, Kolta MG, Paule MG, Scallet AC, et al. (1989): Behavioral and neurochemical effects of orally administered MDMA in the rodent and nonhuman primate. Neurotoxicol 10:529-542.

Sulzer D, Sonders MS, Poulsen NW, Galli A (2005): Mechanisms of neurotransmitter release by amphetamines: a review. Prog Neurobiol 75:406433.

Vollenweider FX, Gamma A, Liechti M, Huber T (1998): Psychological and cardiovascular effects and short-term sequela of MDMA ("ecstasy") in MDMA-naïve healthy volunteers. Neuropsychopharmacol 19:241-251.

White SR, Obradovic T, Imel KM, Wheaton MJ (1996): The effects of methylenedioxymethamphetamine (MDMA, "Ecstasy") on monoaminergic neurotransmission in the central nervous system. Prog Neurobiol 49: 455-479.

Yamamoto BK, Nash JF, Gudelsky GA (1995): Modulation of methylenedioxymethamphetamine-induced striatal dopamine release by the interaction between serotonin and gamma-aminobutyric acid in the substantia nigra. J Pharmacol Exp Ther 273:1063-1070.

Yamamoto BK, Spanos LJ (1988): The acute effects of methylenedioxymethamphetamine on dopamine release in the awake-behaving rat. Eur J Pharmacol 148:195-203. 